\title{
Using Emojis: Self-Presentation and Different Meaning Creation Approaches
}

\author{
Doç. Dr. Sibel Onursoy \\ Anadolu Üniversitesi, İletişim Bilimleri Fakültesi \\ sonursoy@anadolu.edu.tr \\ Orcid: 0000-0002-6414-0454
}

\begin{abstract}
Nowadays visuality is increasing. One of the remarkable developments in 2015 was that the emoji 's ', the smiley with tears of happiness- was chosen the "word of the year" although it was just a pictogram, not even a word. This situation clearly shows that there is an increasing demand for new visual forms of writing. Emojis allow people from different language and culture backgrounds to communicate more effectively and initiate interactions when it is needed. It is believed that emoji codes might function like a universal language that is likely to solve potential misunderstandings experienced in intercultural communication. In one way it might be considered a sort of development in technology, or the other it is just a temporary crazy novelty brought by the Internet. This study mainly aims to explain the dimensions and importance of the emojis' usage. This qualitative study uses semi-structured in-depth interview technique. People tend to employ a sort of expressive use through "emotion laborer" emojis while presenting themselves. Emojis are traces of the transition from instrumentalism to expressionism.
\end{abstract}

Keywords: Social Media, emoji, visual literacy, self-expression

DOI: $10.16878 /$ gsuilet.500954 


\section{Résumé}

\section{Utilisation d'emoji: processus d'auto-présentation Et création de différents sens}

De nos jours, la visualisation devient de plus en plus importante. L'un des développements remarquables de 2015 était que les emoji ": ", le smiley avec des larmes de Bonheur - a été choisi le "mot de l'année" - bien que cela soit juste un pictogramme. Cette situation montre clairement qu'il existe une demande croissante pour de nouvelles formes d'écriture. L'émoji permet aux personnes de différents milieux linguistiques et culturels de communiquer plus efficacement et d'initier des interactions en cas de besoin. Le code émoji pourrait fonctionner comme un langage universel susceptible de résoudre d'éventuels malentendus dans la communication interculturelle. Cela pourrait être considéré comme une sorte de développement dans les formes d'écriture et d'alphabétisation, ou juste une nouveauté temporaire apportée par l'internet. Cette étude vise principalement à déterminer pourquoi les émoji sont importants pour les utilisateurs. Cette étude qualitative utilise une technique d'interview semi-structurée en profondeur. Les gens ont tendance à utiliser les émojis "émotifs" pour s'exprimer. Les émojis sont des traces de la transition de l'instrumentalisme à l'expressionnisme.

Mots clés: Médias sociaux, emoji, émoticônes, l'expression de soi. 


\section{Özet}

\section{Emoji Kullanımı: Kendini Sunma ve Farklı Anlam Yaratma Yaklaşımları}

Görselliğin etkisi giderek artmaktadır. 2015 yılının en dikkat çekici olaylarından biri, bir piktogram olmasına rağmen, "Sevinç gözyaşı olan yüz ifadesi; ' emojinin, Oxford Sözlügünde "yılın sözü» olarak seçilmesidir. Bu durum internet çağında yazıya dair uygulamalar üzerinde yeni görsel üretim taleplerinin olduğunun göstergesidir. Emoji, farklı dil ve kültür çevrelerinden insanların daha açık bir şekilde iletişim kurmaları ve karşılıkı etkileşimde bulunmalarına izin vermektedir. Emoji kodu, uluslararası iletişimin daima var olan anlama sorunlarını çözmeye yardımcı olabilecek evrensel bir dil olabilir. Bir taraftan teknolojik gelişmenin bir göstergesi diğer taraftan sadece internetin getirdiği geçici bir tuhaflık olabilir. Bu araştırma, emojilerin kullanıcılar için kullanım boyutunu ve önemini açıklamaya yönelik bir girişimdir. Bu nitel bir araştırmadır ve yöntemi yarı yapılandırılmış derinlemesine görüşme tekniğidir. Insanlar duygu işçisi emojileri ekspresif olarak kullanır ve kendilerini sunarlar. Emojiler araçsalıktan dışavurumculuğa geçişin izleridir.

Anahtar sözcükler: Sosyal medya, emoji, kendini sunma. 


\section{Introduction}

Emoji are commonly used to simplify an emotional expression or to enrich user experience. Being an interesting application of computers, emoji are being preferred by a large number of internet users in various electronic devices or in many applications. Used to supplement or substitute plain texts, emoji were first introduced as "picture" (e) + "characters" (moji) in Japanese electronic messages and Web pages. Later, they were encoded in the Unicode standard for indexing characters (722 codes were included in version 6.0 of the Unicode and 291 were added to version 7.0 and 8.0). As of June 2018, the total number reached 2777 (http://unicode. org/emoji/charts/full-emoji-list.html). Since they were encoded as Unicode, their popularity rapidly increased all over the world. In addition, emoji became an interesting component of data processing applications. Being compact and vivid, these emoji were embedded into many applications developed for smart phones and tablet computers. So, they are now often used and shared by a large number of users from different demographic and cultural backgrounds in the world. Emoji soften potential spirit of digital life as a moderate and common form of vernacular. These symbols play an important role in emphasizing the tone, introducing a sort of humor as well as vividness and identity to plain texts. Also, emoji are used as a strategy to cope with emotional problems and a new creative form of expression in addition to their sincere nature. In addition, due to their resemblance with real objects, emoji have been reported to be similarly understood by people in different cultures (Barbieri, Kruszewski, Ronzano, \& Saggion, 2016) and have been claimed to be "the world's first truly universal form of communication" (Evans, 2017).

\section{Literature Review}

\section{The Origin of Emoji}

The birth of (smile) emoji dates back to 1963 when a public relation campaign used them as a part of a motivational strategy following the chaos and work loss due to the merging of some companies in the USA. A yellow face with a smile designed by Harvey Ball, an advertiser, was printed on badges attached on dresses and bags. Ball's design rapidly gained considerable ideological and economic popularity; however, he couldn't receive its copyright. In the late 1960s, "smiling face" was printed on many daily objects such as t-shirts, buttons etc. Later, in the early 1980 s, its popularity increased and it became a permanent representation of popular culture in the West. It was possible to see it on pencil cases and even on Acid-House record covers (Stark and Crawford, 2015, p. 2)

Figure 1. Acid-House Record Cover




According to Gophinath (2013), emoji form a sort of dynamic that involves a series of dialectic processes such as emergence, popularity, normalization and decrease in popularity. The content of this dynamic can be used for different purposes again and again and it helps nostalgia to be revived. According to Sarah Ahmed (2010), emoji "affects individuals differently depending on the context and the objects involved" (p. 29).

This practical way of expressing emotions has become more prevalent in computer-based social interactions of daily life. Some text-based images such as :-) and :-( the vertical and horizontal images of a face known as "kaomoji" or "face symbols" and introduced by Japanese- looked quite natural but complex; it was necessary to use more characters to create a different image. This complexity might be one of the reasons why emoji were developed in Japan for the first time (Mullaney, 2012). Therefore, the first digital emoji was designed by Shigetaka Kurita in 1999, an employee working for a mobile internet platform (NTT DoCoMo, i-mode mobile Internet) in Japan because e-mails were limited to 250 characters then. He believed that this design would result in faster and easier communication (www.theguardian.com). What inspired Kurita emoji for the first time was the "heart" symbol, which was popular among young people in 1990s, so its first design was "heart" emoji that represents love.

Prior to the emergence of emoji, it was difficult to convey emotions in written communication due to the lack of facial expressions and use of body language (Walther and D'Addario, 2001). People tended to use the images formed through ASCII text to find a solution to this problem. Some researchers claimed that such visual clues are useful in increasing visual value of a text and enabling individuals to express themselves (Walther and D'Addario, 2001; Dresner and Herring, 2010).

\section{Emoji Studies}

Some studies in popular media (Negishi, 2014; Sugiyama, 2015) emphasize the popularity of emoji among users of mobile texting applications such as WhasApp and Facebook Messenger during their communication. Many emoji have been created so far and they technically help users to express their emotions. However, the simple relationship between emoji and emotional expressions is quite problematic. As Naomi and Baron stated, face images and their meanings evolve, increase in variety and change according to the context just like certain words do. Although people were successful in written communication without using emoticons in the past, the expression of meaning has now become more and more vague (Naomi and Baron, 2009, p. 131). According to Dresner and Herring (2010), common emoticons (images of thought and emotions) are limited to icons, and they have illocutionary force (the possible behavior a person shows when he experiences a situation). These emoticons help to convey an important part of the meaning the linguistic structure has, and give 
clues about what is intended by users in their writing. Emoticons also function like punctuations in a text (Dresner and Herring, 2010, p. 26). However, although they are commonly used in social media, their functions are not clear enough yet. Damasio (2005) explains the relationships of emoticons and emotions with body through biological mechanisms. According to Damasio, "emotion is the sum of changes that occur depending on certain mental images triggered by a special brain system" and "the essence of emotions is the experience of changes due to the sequence of mental images that trigger the loop (cycle)" (Damasio, 2005. p.145). According to Illouz (2007), emoticons is an "internal energy" that activates and encourages individuals for action. Emoticons highlight the cultural definitions of concrete, simultaneous and permanent identities and define the existing relationships in social terms (IIlouz, 2007, p. 2-3).

According to Sugiyama (2015), emoji have two basic functions: They help people -especially young ones- to manage the communication climate as well as to construct and express their aesthetic self. The first function includes emotional expressions but the emotional expression is not necessarily used to convey the emotions these users feel; it is the emotions that they need to convey in order to construct and maintain pleasant relationships. In this way, people engage in a sort of affective labor via emoticons. This helps them monitor and fine-tune background feelings of themselves and their interactants, contributing to an amiable communication climate. In the second function, emoji serve as an aesthetic expression rather than an emotional expression. By using the correct emoji in correct situations, even adults may express their taste and improve their aesthetical point of view. This aesthetic aspect of emoji use appears to be quite gendered. The use of emoji is an essential part of fashioning the self, as the aesthetic aspect with emoji becomes a part of how they define and redefine themselves just like mobile decoration (Sugiyama, 2015).

Emoji provide new ways for the expression of digital emotions, and they play

certain roles in economic activities as well. For Hardt, Illouz, and other theorists of affect, the radical challenge of the neoliberal economy is posed primarily by "the affective labor of human conduct and interaction" - or as Hardt calls it, the "other face of immaterial labor" (p. 90). "We increasingly think like computers," Hardt argues of immaterial labor, "and the interactive model of communication technologies becomes more and more central to our laboring activities" (pp. 94-95).

According to Sarah Ahmed, "affect is what sticks to people, places, and objects". (2010, p.29). According to Stark and Crawford (2015), emoji as historical and cultural objects, technical constructs, and instances of the techniques of computational control within communication platforms. Above all, these graphic forms are exemplary of the tension between affect as liberating human potential, and as a productive force that the market continually seeks to harness through the commoditization of emotional sociality. The lexicon of emoji character set 
limits the expressions of emotions (Stark and Crawford, 2015). Laura Mark's term "lame infinity" (2010), which explains the methods applied by technology to produce repeating similarities, is clearly reflected in the statements of the participants. Emoji seem to be limited by a normcore emotion system, a unique base of digital communication. In other words, it is somewhat limited due to specific characteristics of digital communication (Stark and Crawford, 2015, p. 4).

John McWhorter described spoken language and written language as two separate forms of communication that are governed by different norms, and he said that SMS messaging has developed a textual form of spoken language. $\mathrm{He}$ described spoken language and written language as two separate forms of communication that are governed by different norms, and he said that SMS messaging has developed a textual form of spoken language. (Mclntyre, 2016, p. 34). Emoji, in essence are an expression of emotion and sentiment, and as a means of delivering creative non-verbal content in a digital medium are both old and new (Alshenqeeti, 2016, p. 64).

According to Danesi (2016), people use similar emoji in similar discourse mainly because now the basic emoji is standardized. A universal emoji code actually fosters a better communication by emoji between both native and cross-cultural users, despite the fact that people in different cultures interpret the same emoji forms quite differently. His analysis reveals that the use of emoji can elicit many kinds of discourse meaning. For example, it can express phatic meaning such as utterance opening, ending and avoidance. It can also involve an emotive function that expresses interlocutors' feelings and emotions by visually emphasizing a point of view of an emotion or by substituting facial expressions with emoji equivalents. Also, Danesi reviews previous attempts to build a universal or common language, arguing that the emoji code has the potential to evolve into a universal code (p.162).

\section{The Aim of the Study}

This study aims at determining the importance given to emoji use, the motivational factors leading to their use, the positive and negative features of emoji in terms of the meanings of emotional behaviors, as well as the meaning changes. Based on the research of emoticons (Sugiyama, 2015; Dresner \& Herring 2010; Derks et al. 2007).

\section{Method}

This paper is based on the analysis of qualitative data. The population of the study is emoji users who are over 18 years old and live in Turkey. The emoji examined in this study were determined through convenience sampling, which is one of non-probability sampling techniques. In non-probability sampling "the researcher does not attempt to generalize the findings obtained (Erdoğan 2012, 
p. 208). Therefore, the findings are valid only for the group in focus. The sampling of this study includes a total of 16 people (10 females and 6 males) who own smart phones and use emoji applications. The average age of the participants is 30 (ranging between 22 and 48). Interviews were conducted individually, and the emoji use lists of the participants were examined by getting their permission. The participants include graduates, students and academicians who are more likely to express their personal experiences and reflections (Lindlof, 1995). All the informants were mobile telephone users.

Figure 2. Features of participants.

\begin{tabular}{|l|l|l|l|}
\hline Participants & Age & Gender & Profession \\
\hline P1, P2 & 42 & Female & Teaching staff \\
\hline P3 & 22 & Female & Undergraduate \\
\hline P4 & 25 & Female & Undergraduate \\
\hline P5 & 24 & Male & Undergraduate \\
\hline P6 & 25 & Male & Undergraduate \\
\hline P8, P16 & 38 & Female & Worker \\
\hline P9 & 28 & Female & Secretary \\
\hline P10 & 23 & Male & Material engineer \\
\hline P11, P12 & 30 & Female & Research assistant \\
\hline P13 & 22 & Male & Graduate student \\
\hline P14 & 24 & Male & Undergraduate \\
\hline P15 & 25 & Male & Undergraduate \\
\hline
\end{tabular}

The study uses semi-structured in-depth interview technique, a qualitative research method. Yıldırım and Şimşek (2005, p. 30) suggest: "social phenomenon can be understood by analyzing the unique dimensions of each single situation (s. 29) rather than generating generalizable laws that determine social behavior, which requires the use of different research methods and techniques. One-to-one interviews are voice-recorded. The total duration of interviews is 435 minutes; the shortest being 12 minutes and the longest 45 minutes and the average being 25 minutes. The transcript of the recordings is a text of 7984 characters.

The data obtained from the interviews are analyzed on the basis of hyper coordination theory (Ling and Yttri, 2002). Mobile communication systems meet the communication need of social groups, which is a significant and functional activity. Hyper coordination adds two more dimensions to this. The first one refers to the expressive dimension of mobile phone use. In other words, this device provides a sort of basic coordination for emotions and social communication regardless of time and place. People communicate for various purposes ranging from chat, chain messaging, innocent and sincere congratulations to cheap pornographic images. Mobile phone use leads to such an integration. The second one is about how you present yourself during a chat or discussion. In other 
words, telephones become an environment where you present yourself. Therefore; hyper coordination involves the functionality and influence of telephones as well as the structure related to the presentation of self.

By using continuous comparison analysis, the concepts emerged right after one phase of data collection are included in the next phases of data collection in the study. The aim of this process is to obtain supplementary data regarding concepts, themes and the explanations about their relationships with each other. The repeating cases and situations stated by the participants throughout the study, the problems they noticed and the examples provided throughout the research are taken into consideration (Strauss and Corbin, 1998, p.130)

\section{Findings and Comments}

\section{The Importance of Emoji and Their Features}

Emoji help convey an important aspect of the linguistic utterance they are attached to: what the user intends by what he or she types (Dresner and Herring, 2010, p. 256). The participants report that emoji are used to seize a chat-like tone in digital environment (Sugiyama, 2015). Similarly, they are believed to soften the message by replacing voice tone and mimics, to provide opportunities for figurative and cynical language, to add emotions to message by strengthening the meaning, to verify the information, to foster sincerity and to make the meaning stronger. They are also used for the sarcastic approach in social media. The participants think that emoji has positive effect on communication:

"Plain text is not enough to reflect the tone of the speech, as well as the emotions. Emoji substitutes intonation and mimics, softens the message, strengthens the meaning and adds emotion" [P2, P8, P9, P13, P11, P10]. "When a user uses emoji together with his words, it feels as if I hear his voice" [P14]. "Emoji have the power to reveal figurative meaning. I mean to tell something serious, but I do allusions by using figurative meaning. There is a hidden message here" [P6]. "You add a smiling face; this misunderstanding can be avoided by highlighting the message "this is humor; get it" [P4]. "People use them while doing an irony so that they don't get into trouble [P5].

The frequency of emoji usage varies according to the platform used, the status or the sincerity of the individuals. Most of the participants have concerns about the potential problems when emoji are used in formal situations and they believe that emoji are more appropriate for daily and informal use. Facebook is often viewed as an official environment, so emoji use is avoided. Facebook is often seen as an official environment, so emoji use is avoided:

"I don't use emoji in Facebook (shares or messages). It is a public area" [P11, P14].

Some participants report that they use them to soften the hierarchy:

"I often use emoji to soften the hierarchy" [P4]. "When you write to your 
boss, you have to be careful about his status. If you send him/her a fist, 'biceps' or 'gun', he might misunderstand you. But using emoji while texting to close friends won't cause any problems" [P6]. "There are different meaning transformations. I am very careful when I write or text to a serious person. I don't prefer to use emoji" [P3].

The frequency of emoji use varies depending on the age range and users' experiences. As Prensky remarks, digital natives are very competent with in dijital world and can speak the digital language of the internet very well. (Prensky, 2002, p. 2). Prensky highlights this difference as follows: Although most of digital immigrants keep up with this technology, they do not lose their ties with the past. The most prominent feature of these digital immigrants is that they prefer the internet as the second option, not the first, for information search purposes. In other words, they are quite different when compared to their children in terms of socialization, and they are still learning a new language. According to Prensky (2009) digital tools become widely available, digital enhancement will become even more vital for everyone. For this reason, technology should be quickly adapted to education $(2012,2016)$. Digital natives aim to access information very fast. They are fond of parallel processes and multi-tasks. They prefer visuals to texts and random access (like hypertext). Similarly, they function best when networked and thrive on instant gratification and frequent rewards. They prefer games to "serious" work. However, digital immigrants typically have very little appreciation for these new skills that the natives have acquired and perfected for years of interaction and practice. These skills are almost totally foreign to the immigrants, who themselves learned - and so choose to teach - slowly, stepby-step, one thing at a time, individually, and above all, seriously. (Prensky, 2001, p. 2). These ideas are clearly supported by the participants who verify the differences between natives and immigrants by uttering the following common ideas:

\footnotetext{
"The use emoji varies according to age. Emoji use is not important for those who were introduced to technology at later ages, but young people almost use no words". "I only use emoji when I think that I won't be able to convey the intended message" [P14]. "Young people use a greater variety of emoji. It is hard to follow these conversations. Young people understand each other but we cannot" "I agree with it; young people should not also use (emoji)" [P8, P16]. "Young people communicate at basic level; short and fast. We are more conservative; young people do not have concerns about possible harms to their status. They do not respect hierarchy especially in social media. Everybody is equal in social media environment. That is millennium generation" [P2]. "There is a generation gap" [P15].
}

While some of the research on the internet use reveals that men are addicted to the internet more than women (Esen and Siyez, 2011; Balta and Horzum, 2008; Cao and Su, 2007; Günüç, 2009; Johansson and Götestam, 2004; Morahan-Martin and Schumacher, 2000), others reveal no differences between sexes in terms of internet addiction (Bayraktar and Gün, 2007; Jang, Hwang and Choi, 2008; Kim et.al., 2006; Pawlak, 2002). It is thought that this difference might be due to data collection or analysis methods or certain variables such as 
cultural differences. Some researchers note that women use emoji/emoticon more often than men (Tossell et al. 2012; Fullwood et al., 2013; Swiftkey, 2015; Nishimura 2015). Findings of this research support this judgment. According to the male participants of this study, emoji use varies according to sexes. They highlight that females use emoji more than men because they- especially young girls- are good at expressing emotions and have stronger sense of aesthetics. Also, this style is believed to be a feminine style of chatting which is specific to women. Male participants also report that emoji are not popular among men except some use of abbreviations.

"A male does not send emoji to another male. If there are females in a group, the use of emoji increases. Men send soccer emoji the most. If there is a football match at the weekend, they send a soccer ball and write the time instead of writing a full sentence. In other words, males use emoji mostly as abbreviations" [P13]. "The women (who like chatting) use emoji more often [P1, P6, P14]. They use them better and more effectively. Women control their emotion expressions better" [P14].

The use of emoji varies by gender. They are considered to include feminine and masculine species.

"For example, I send my male friends black heart instead of a red one. Red is quite feminine. I make a distinction between men and women when using" [P3]. "Women mostly use flowers, insects, fish etc." [P1].

Emoji help to feel the mood of a chat and the tone of a relationship. With emoji experience, people may infer about the things that are not expressed concretely. This implicit communication is consistent with Damasio's ideas: "a minimalist in tone and beat, the feeling of life itself, the sense of being" and "corresponds instead to the body state prevailing between emotions" (Damasio, 2005, p. 150). In addition, the findings also support Sugiyama's statement, which states: "emoji helps users monitor their own emotions and the emotions reflected in their interactions":

"I have a Bengal friend in my Facebook account and he writes in Bengali. He does not use Latin alphabet letters but I can understand the mood of him shares because of the emoji he uses" [P11]. "You can make comments by using an emoji for posts shared by foreign people even if you do not know their languages" [P13].

Emoji emerged in digital form to ensure fast and easy communication. This idea is supported by the following statements of participants:

"We can write 20 messages in a minute. It has an advantage: it is fast" [P5].

"They make communication faster. If you do not want to make a long talk, you can use them" [P11]. "It eliminates the risk of making mistakes while thinking about what you write" [P1].

In addition to being a symbol for emotional expressions, emoji serve for the purposes of aesthetics and fun as well (Sugiyama, 2015):

"Since emoji have a great variety, it is possible to find the right one according to 
the theme of the message. They make the conversation more vivid" [P1, P2]. "I use them to make the text look cute, it looks well and it is fun too" [P3]. "They embellish the screen" [P11].

Goffman defines social environments that involves two or more people as "interaction order" (Goffman, 1967). Goffman's "interaction order" consists of verbal systems such as the rules for a game, a traffic code system or the syntax of a language (2009). By using "self-presentation" concept, Goffman explains how individuals present themselves when they interact others, and what type of strategies they use for this purpose. Self-presentation strategies, which may be noticed or remain unnoticed by others, may vary according to the personal characteristics of individuals. This situation can be defined by Goffman under the concept "dual self". According to Goffman, consensual self refers to the presence of "self-player" and another self shaped during interaction in one individual. When an individual interacts with others, he or she actually come out on the "stage". At this stage, he or she prefers to interact by sharing some things or hiding some facts. The expression of individuals is performed through self-presentation. However, there is a backstage in this process, which allows individuals to abuse the role they play to preserve their own sacred values (Goffman, 1967). Thus, the agreement due to social interaction is not complete agreement and it is defined as "surface of agreement" rather than full agreement, which paves way to the conceptualization of "working consensus". In addition to being an individual strategy, self-presentation is a process guided by linguistic mechanisms (Goffman, 2009; Bayad, 2016, p. 83). Emoji help individuals to define themselves (Sugiyama, 2015) and play an important role is shaping "the self". Self-presentation is natural in social media for participants:

"I use "gun" together with "chick". They both symbolize "me". I am a chick, but I am not that innocent." [P4]. "I use heart together with flower. This is a personalized 'end point' for me" [P5]. "I am able to represent myself with a stuff I associate myself with. If I were able to design my own emoji character, I would use it like a nickname" [P1, P11]. "I always use sky emoji, in fact that is "me" [P13]. "Red balloon is very cute. That is "me" [P12]. "If people know me, they recognize my emoji easily. Social media has a special language and your real-life language is different than that. You have a different identity there and you do not need to be ashamed of it." [P14].

The findings of this study clearly support Dresner and Herring's study (2010: 256) which reveals that emoji might function as punctuations (emphasizing, ending and continuing etc). They play an important role in continuing or ceasing a conversation:

"I use more than one emoji to emphasize 'very much'. Heart emoji is the last full stop to finish texting." [P15]. "I add a gun to the text to emphasize how serious I am", "I use emoji when I I do not want to make a full sentence" [P5]. "I add a fist or gun emoji to emphasize or strengthen the meaning" [P6]. "“2 is the last fullstop to finish the chat 'Kisses, see you" [P1, P2, P3, P4, P5, P8, P9, $P 10, P 11, P 12]$. "The more you repeat, the stronger the meaning gets" [P12]. "It is used to end a chat or to continue the flow. You do not physically laugh 
but you add two emoji to mean "it is funny'. It is a way to react." [P14]. "It is used to shortcut the conversation" [P13]. "You add the emoji to make her/him happy" [P12].

The use of happy emoji is more common than crying or sad ones. According to the statistical data collected by Twitter regarding the use of emoji, the most commonly used are the three emoji happiness and approval of expression in Turkey.

Figure 2. Top-tweeted emoji in the global top 10 ranking (7.1.2015-

$$
\text { 6.30.2016) }
$$

The use of emoji for sad or serious situations is limited in social media. So numerical data for the use of emoji may not reflect reality. Resource: https://twitter. com/twitter/status/754842903625596928/photo/1

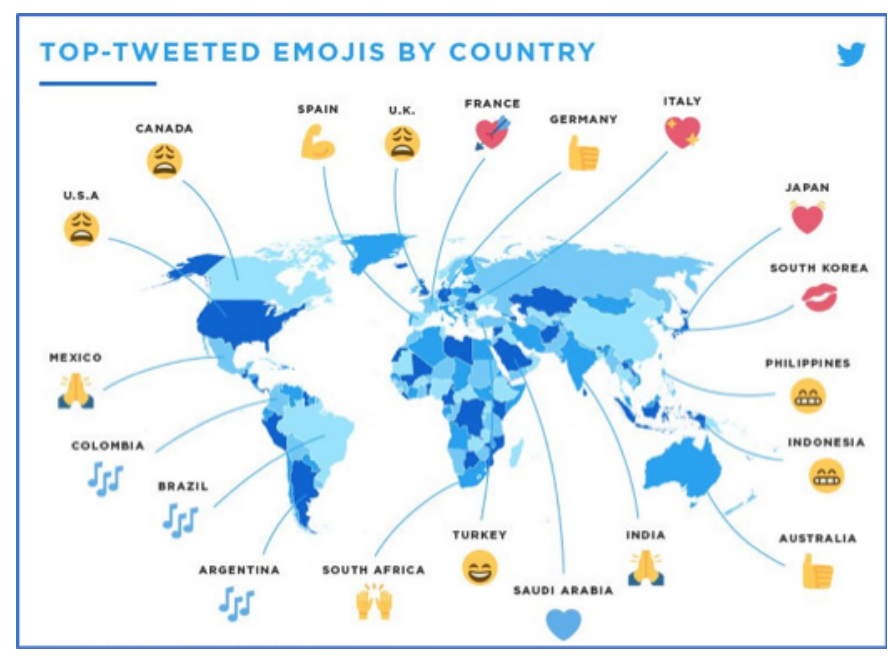

According to the data provided by Twitter, the most often used emoji is " $\hat{\theta}$ " (smiling) and the second one is the emoji ( $\mathrm{k}$ ) representing "OK". The third most common emoji is a ":- (smiling) emoji. The statements of the participants clearly support this finding:

"I use to say OK [All participants except P6, P8 and P12, who prefer or of to express OKJ.

According to participants, the reason for the frequent use of happy expressions is the widespread ironic approaches on the internet:

"Habitual sarcasm is spreads on the internet. People can easily make fun of others there (the internet environment). Therefore; the emoji representing laughing, smiling, laughing out loud and stick-out-tongue are used very often" [P16]. "When it is a sad situation, emotion is often expressed only with one emoji." "For instance, when we get upset about news, we do not want to write too much, you add emoji one after the other for a funny stuff", "This is true only for funny stuff. It is not suitable for serious topics" [P14]. 
According to the participants, short chats in sad situations and the suitability of digital environments for irony are important factors leading to high rates of "happy" emoji use in Turkey. Thus, the emotional reality reflected by the frequency of emoji use (emoji ranking) (Fig. 2) is often doubtful for Turkey. As well as, this kind of algorithmic expressions of appreciation in social media can be misleading.

\section{The Negative Features of Emoji}

Emoji not only provide news ways to express emotions but also serve for the market. For instance, when "like" icons used for digital products reach to a certain level of popularity, they might be used to earn money. This "like" button attracts users to click on advertisement and some people earn money by taking the advantage of people's weakness for this icon. As Stark and Crowford have expressed, the emoji has become 'a producing power' in the way of 'commoditization of social feelings' (2015). In other words, in this sense, emoji support the formation of superficial data culture:

"There are companies trying to obtain data about public opinion via the internet. For instance, up ( I ) and down ( I) In fact, the sharing of ideas and information in social media is reduced to a fast data aggregation.

There are only quantitative results; not a detailed research" [P14].

According to the participants, irony is encouraged by the use of emoji. Anonymous identities and the artificiality of the environment lead to the emergence of behaviours that would not normally occur in a real environment:

"People make fun of serious and sensitive issues in social media. In fact, it is not funny; tragical. Mocking is very trendy", "When you make fun of somebody in real life, we feel ashamed. But in social media there is no need to feel ashamed." [P14].

According to Hardt, since people increasingly think like computers, certain activities such as emoji use become basic issues discussed in communication technologies (1999, p. 94-95). The fact that emoji use hinders idea sharing and causes more superficial communication is clearly supported by the findings of this study. It is also believed to decrease vocabulary richness. It is thought that the presence of too much visual elements may negatively affect the production of deep thoughts and richness of ideas:

"It leads to a bad habit. Using an emoji instead of commenting, prevents sharing ideas", "You cannot go deep 'in thoughts'; (it is) just superficial communication" [P14]. "We use emoji to be fast; we do not get involved in deep conversations" [P5]. "The reasons why people use emoji too often, are their limited vocabulary and internet applications cause this" [P13]. "It (the use of emoji) detroys our (language) Turkish. Especially the young people cannot communicate in a real sense" "A new generation of young people emerge who think less, use fewer words, can not express themselves" [P8, P16]. "Young people prefer seeing rather than reading" [P12]. 
According to Baron (2009), the meanings of emoji are vague. Common feelings and thought are limited by such icons. Participants anticipate that the use of emoji is both a limit to real thinking and a barrier to expressing real emotions:

\begin{abstract}
"In fact, you think through words. If you know the word, you have its equivalent in your mind. A generation who uses emoji too much will have limited vocabulary knowledge, so thinking will be limited. We mostly see concrete things in emoji such as train, car etc. You cannot find abstract emotions in emoji. In the future, there will be more pople who cannot express themselves" [P2].
\end{abstract}

\title{
The Transformation of Meaning of Emoji
}

Emoji enable people to apply a secret or encoded way of messaging; which is a sort of secret language. Each individual may interpret emoji in a different way. They are prone to be interpretated differently due to their visual nature. Psycholinguistic theory suggests that interpretation of a situation or object must be consistent between two people in order to avoid communication problems (Miller et al, 2016, p. 266). The meanings of emoji evolve, increase in variety and change according to the situation (Baron, 2009), they sometimes carry personally unique meanings and even they are disregarded by users. Communication works on the basis of general consensus, illocituonary force and habit in individual and group relations. In other words, superficial agreement and 'a work consensus' plays a role, as indicated by Goffman (2009). In this context, cultural differences are not felt:

"We play an emoji game with my friend. We write the lyrics of a song by using emoji and my friend tries to guess the song, we understand each other" IP4, P3]. "Those involved in illegal practices can take the advantage of this situation to communicate by using emoji. A secret language may develop. Meaning is not important." [P14]. "People have codes. For instance, I can define some of my friends with the emoji they use" [P13]. "Children uses the emoji I have never used, monster images, for example. It has been a new language for them. They use only those emoji to chat and write less. Although I also use emoji, I feel alienated." [P9]. "ـ is an emoji I use to mean 'Thanks God'. In fact, it means something else but I continue to use it with this meaning" [P1, P2, P6].

When some emoji are used together, they can carry a different meaning than they have when they are used alone. Also, they can even be used as a secret code (for instance sexual content, slang etc.):

"I do not use, but it carries a different meaning; such as peach and eggplant the lauges)" [P6]. "They use it as curse by selecting emoji randomly" [P16].

When the reality does not match with the presented reality and this framed reality increasingly replaces the existing reality, mediatic reality starts to root in the minds of individuals and the existing reality totally changes. Mediatic reality affects the experienced reality and slowly replaces it, which might lead to cultural alienation, weakening of the feeling of belonging, social alienation as well 
as social disintegration. Media, which is the most effective component of culture industry that verifies culture imperialism concept of critical school, manipulates the cultural structure of the society using its own mentality according to its needs and benefits. It produces new forms addressing the masses and behavior patterns that fit to these forms (Güneş 2001, p. 127-128). It is possible to see

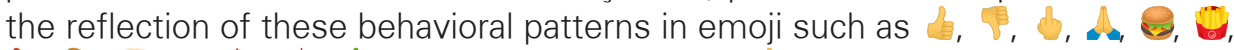

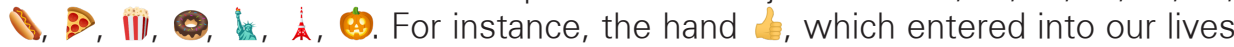
first thanks to American movies, turns into a common language as an example of dominant cultures. Emoji have cultural transformations of meaning; however, all the participants (except one) do not care about these meaning transformations and do not have any concerns about cultural degeneration:

"There is meaning transformation. When I messaging Indian, I realized that Indians do not use (..) emoji. Because it is sacred according to their beliefs" [P14]. "Thanks god (॥). Even if I know the meaning, I use it to mean this meaning (thanks god)" [P2]. "As a negative emoji, we have brown ice-cream. I use as a pile of poo. In fact, it is ice-cream (I did not know that). Everybody uses it as a pile of poo" [P12]. "Like this emoji (Person tipping hand). These are just details and may cause chaos" [P13]. "I use to mean OK. But it may mean threat. In Instagram, someone sent this " (person fencing) to mean "I attack with a Doner knife". There are meaning transformations, in fact" [P12]. "The most problematic emoji is 'red heart'. Since love is perceived differently in Turkey, I can send it only to a very close friend of mine. But this emoji might be misunderstood: Is she in love with me?" [P 9]. "The lives with American films and turned into a common language as an example of dominant cultures. Ideological. There is 'doughnut', there is no 'simit'. I think it is a cultural imposing" [P15].

Under the influence of capitalist production mentality, media has experienced a great transformation in pursuit of commercial success and become a structure serving for mass culture through certain programs whose main function is to satisfy economic benefits (Swingewood 1996, p. 165, 170). The participants indicate that they are encouraged to use emoji. They are aware of the commercial approach:

"You send emoji instead of candy like a prize. There are some applications to customize photographs. There are commercial reflections as well. We see the movie, on pillows, glasses, bottles, hairclips, earrings, films. " [P12]. "They have been sector each" [P15].

\section{The Insights About the Future of Emoji}

The lexicon of emoji character set limits the expressions of emotions (Stark and Crawford, 2015). Laura Mark's term "lame infinity" (2010), which explains the methods applied by technology to produce repeating similarities, is clearly reflected in the statements of the participants. Emoji seem to be limited by a normcore emotion system, a unique base of digital communication. Even if the use of emoji increases, it is believed that not every emotion can be expressed through emoji and the need for written communication will remain. The participants also remark a tendency towards visuality rather than writing. They 
agree that emoji form a universal language. They even hope to have a "customized emoji" through which they will be able to express themselves better. Some participants reflect an awareness about the fact that transformation of words into emoji is a sort of "enforcement":

"People tend to use visuals that might represent themselves rather than writing. Designing an avatar for each individual. That might be the future [P1]. "It is already a universal language and easy" [P4].

"You write and the image appears. It has already become a language" [P10]. "It may supplement writing but cannot replace it. I do not know whether it makes it easy to understand the message. You can express "I love you" with a heart but how can you express "I miss you". A superficial and popular communication type" [P2]. "We will have a new generation of young people who express themselves with fewer words, think less or cannot express themselves. It is an obligation of our modern age. It is not weird. Literacy concept has changed since the emergence of the internet" [P8]. "We may call it a kind of weird novelty brought by the internet, but it is necessary in this modern era. We need to learn about it to understand the language of the young. Writing is about to lose it importance" [P16].

The fact that social media has strengthened its influence in mobile environments and touched every part of human life have greatly affected individuals or societies. Also, social media is centered. When individuals are influenced from each others' actions and experiences, including the emoji use, and share them with others, globalization process is positively affected from this situation. As the new experiences of this new process are examined and shared more and more, will be understood the reasons and consequences as well as possible future trends better.

Schiller (1993, p. 40) states that media is an industry itself, they are not independent of each other. According to Schiller (1993, p. 40), the images and messages media gives and its objectives highly depend on the maintenance of profitability and consumption culture based on private property. Mass culture, which is convenient for instant consumption of masses in every part of life ranging from music and literature to clothing and food, is a culture based on information produced by large capital in industrial environments, expected to be uniform, easily consumed, always different and new and easy to consume, shaped by mass communication tools and that provides temporary satisfaction for its consumers (Güneş, 2006, p. 128). Media, which is the most effective component of culture industry that verifies culture imperialism concept of the critical school, manipulates the cultural structure of the society applying its own mentality according to its needs and benefits. It produces new forms addressing the masses and behavior patterns that fit to these forms (Güneş, 2001 , p. 127-128). It is possible to see the reflection of these behavioral patterns in emoji integrated into daily life with a hegomonist mentality in mind. When such products do not tally with the pending culture, concepts may lose their essence, cheap tastes may develop, thinking may get shallower, generation gap may emerge and individual may alienate against self-culture and native language. 


\section{Conclusion and Discussion}

Media is a medium of communication that emits all kinds of messages, the masses with different socio-demographic characteristics, by interpreting them according to its publishing policy and formatting according to the characteristics of the medium. Social media is gradually expanding its domain of influence and the penetration of almost every area and moment of human life increases the influence on the individual / society.

Emoji, created as a mass appeal form in the social media environment, brings digital life, color, personality and emotion with cute faces, and quickly and effectively guides the user. In the digital environment, they allow users to emotionally cope with the experience of establishing and maintaining social ties. Emoji help the normalization of social relationships in online environment. According to findings reveal that these cute images might affect language, culture and thinking patterns by causing some changes. Emoji use has some negative features such as, hindering idea sharing, causing shallower conversations, weakened vocabulary, representing false emotions, playing a role in presenting a fake self, allowing mocking and exaggeration, possibility of addiction, giving verbal communication a secondary status, hindering deep thinking, and being abused by culture industry and marketing practices. In addition to making social relationships more vivid and sincere, emoji play important roles in measuring and analyzing emotional interactions as well as making money and uniformity.

Emoji use leads to culture-based varieties in social formation. Emoji affect masses and result in certain behavior patterns as a marketing tool by reproducing the cultural structure of society and social media depending on its needs and benefits. When such products do not tally with the pending culture, concepts may lose their essence, cheap tastes may develop, thinking may get shallower, generation gap may emerge and individual may alienate against self-culture and native language. In this respect, watching visual samples such as emoji as a language of digital environment may be considered an important step in shaping the future of media.

As mobile communication is becoming more and more embedded into life practices, new features and new practices emerge inevitably. To illustrate, it helps to coordinate various daily activities - which is a sort of "mundane coordination". Similarly, individuals' being more aware of what is going on worldwide, being influenced by their interactions and experiences with others -including emoji use-, and sharing these experiences with others may signal a sort of globalization. In addition to functional use, people tend to employ a sort of expressive use which includes "emotion laborer" emoji while presenting themselves. This technology adaptation, which is called hyper coordination, penetrates and changes the life phases of individuals. Emoji play a small role during the transition from functionality to expressionism in these phases of life. 


\section{References}

Alshenqeeti, H. (2016). Are Emojis Creating a New or Old Visual Language for New Generations? A Socio-semiotic Study, Advances in Language and Literary Studies I. Vol. 7 No. 6. Australia: Australian International Academic Centre. http:// dx.doi.org/10.7575/aiac.alls.v.7n.6p.56

Balta, Ö.Ç. ve Horzum, M.B. (2008). Web Tabanlı Öğretim Ortamındaki Öğrencilerin Internet Bağımılı̆̆ını Etkileyen Faktörler. Ankara Üniversitesi Eğitim Bilimleri Fakültesi Dergisi, 41, 185-203.

Barbieri, F., Kruszewski, G., Ronzano, F. \& Saggion, H. (2016). How cosmopolitan are emoji? In: MM '16 Proceedings of the 2016 ACM on Multimedia Conference, 531-535. New York: ACM New York.

Bayad, A. (2016). Erving Goffman'ın Benlik Kavramı ve İnsan Doğası Varsayımı. Psikoloji Çalışmaları Dergisi, 36-1 65-80.

Bayraktar, F. ve Gün, Z. (2007). Incidence and Correlates of Internet Usage Among Adolescents in North Cyprus. Cyberpsychology \& Behavior, 10, 191-197.

Cao, F. and Su, L. (2007). Internet Addiction Among Chinese Adolescents: Prevalence and Psychological Features. Child Care Health Development, 33(3), 275-81.

Danesi, M. (2017). The semiotics of emoji: the rise of visual language in the age of the internet. London: Bluoomsbury Publishing.

Damasio, A. (2005). Descartes' error: Emotion, reason, and the human brain. London: Penguin.

Dresner, E. \& Herring, S. C. (2010). Functions of the nonverbal CMC: Emoticons and illocutionary force. Communication Theory, 20, 249-268.

Dresner, E. and Herring, S.C., (2014). Emoticons and illocutionary force. InPerspectives on Theory of Controversies and the Ethics of Communication (pp. 8190). Amsterdam: Springer Netherlands.

Erdoğan, i. (2002). İletişimi Anlamak, Ankara: Erk Yayınları.

Erdoğan, i. vd. (2002). Öteki Kuram, Ankara: Erk Yayınları.

Erdoğan, i. (2012). Pozitivist Metedoloji ve Ötesi. Ankara: Erk Yayınları.

Esen, E. ve Siyez, D. M. (2011). Ergenlerde Internet Bağımlıı̆ını Yordayan Psiko-sosyal Değişkenlerin İncelenmesi, Türk Psikolojik Danışma ve Rehberlik Dergisi, 4 (36), 127-138.

Evans, V. (2017). The Emoji Code: How Smiley Faces, Love Hearts and Thumbs up are Changing

The Way We Communicate. London, UK: Michael O'Mara Books.

Glaser, B. G. (1965). The Constant Comparative Method of Qualitative Analysis, Social Problems, Vol. 12, No. 4 (Spring, 1965), pp. 436-445 Published by: Oxford 
University Press on behalf of the Society for the Study of Social Problems.

Stable URL: http://www.jstor.org/stable/798843 Accessed: 16/02/2015 14:35

Goffman, E. (1967). The Presentation of Self in Everyday Life. New York: Doubleday.

Goffman, E. (1983). 'The Interaction Order', American Sociological Review 48(1): 1-17

Goffman, E. (2009). Günlük Yaşamda Benliğin Sunumu, Çev. Barış Cezar. Ankara: Metis Yayınları.

Gopinath, S. (2013). The Ringtone Dialectic: Economy and Cultural Form. Cambridge, MA: The MIT Press.

Güneş, S. (2001). Modern Kitle Toplumunda Medya Kültür İlişkisi. Medya ve Kültür, Ankara: Vadi Yayınları, s.127-128.

Güneş, S. (2006), Kitle Kültürü Demokrasi ve Medya, Enformasyon Toplumunun Putları, Ankara: Hece Yayıncilık.

Günüç, S. (2009). İnternet Bağımlılık Ölçeğinin Geliştirilmesi ve Bazı Demografik Değişkenler ile İnternet Bağımlıı̆ı̆ Arasındaki Ilişkilerin İncelenmesi. Yayınlanmamış Yüksek Lisans Tezi, Yüzüncü Yıl Üniversitesi, Sosyal Bilimler Enstitüsü, Van.

Hardt, M. (1999). Affective Labor. Boundary 2, 26(2), 89-100.

Illouz, E. (2007). Cold intimacies: The Making of Emotional Capitalism. Cambridge: Polity.

https://www.theguardian.com/technology/2016/oct/27/emoji-inventor-shigetaka-kurita-moma-new-york-text Accessed: 16/02/2015 14:35

Jang, K. S., Hwang, S.Y. and Choi, J.Y. (2008). Internet Addiction and Psychiatric Symptoms Among Korean Adolescents. Journal of School Health, 78, 165-171.

Johansson, A. ve Götestam, K. G. (2004). Internet Addiction: Characteristics of a Questionnaire and Prevalence in Norwegian Youth (12-18 Years). Scandinavian Journal of Psychology, 45, 223-229. Accessed: 10.10. 2017

Kahraman, Hasan Bülent (2002), “Postmodern Dönemde Gerçeğin Dönüşümü, Medya Ve Popüler Kültür", Postmodernite İle Modernite Arasında Türkiye, İstanbul: Everest Yayınları, S. 191.

Kim, K., Ryu, E., Chon, M.Y., Yeun, E.J., Choi, S-Y., Seo, J.S. ve Nam, B.W. (2006). Internet addiction in Korean adolescents and its relation to depression and suicidal ideation: a questionnaire survey. International Journal of Nursing Studies, 43, 185-192.

Lindlof, T. R. (1995). Qualitative Communication Research Methods. Thousand Oaks, Calif.: Sage.

Miller H., T. S. Jacob, Chang S., Johnson I., Terveen L.and Hecht B. (2016). “Blis- 
sfully Happy" or "Ready to Fight": Varying Interpretations of Emoji, Proceedings of the Tenth International AAAI Conference on Web and Social Media (ICWSM 2016). 259-268.

Martin, J. M. ve Schumacher, P. (2000). Incidence and Correlates of Pathological Internet Use Among College Students. Computers in Human Behavior, 16, 1329.

Mclntyre, E.S., (2016). From Cave Paintings To Shakespeare And Back Again: What Are Emoji And Should I Be Afraid? (Doctoral dissertation). [Online], available from https://digital.library.txstate.edu/bitstream/handle/10877/6100/MclntyreEmily.pdf?sequence=1, [accessed 08.05.2018].

Mullaney, T. (2012). The Moveable Typewriter: How Chinese Typists Developed Predictive Text During The Height Of Maoism. Technology and Culture, 53, 777-814.

Naomi S. and Baron, (2009). "The myth of impoverished signal: Dispelling the spoken language fallacy for emoticons in online communication," In: (Jane Vincent and Leopoldina Fortunati editors). Electronic emotion: The mediation of emotion via information and communication technologies. Oxford: Peter Lang, pp. 107-135.

Negishi, M. (2014): 'Meet Shigetaka Kurita, the Father of Emoji'. [Online], available from

https://blogs.wsj.com/japanrealtime/2014/03/26/meet-shigetaka-kurita-the-father-of-emoji/ [accessed 08.05.2018].

Nishimura, Y., (2015). A sociolinguistic analysis of emoticon usage in Japanese blogs: Variation by age, gender, and topic. In Selected Papers of Internet Research 16: The 16th Annual Meeting of the Association of Internet Researchers.

Özdemir, S. (1998), Medya Emperyalizmi ve Küreselleşme, İstanbul: Timaş Yayınları.

Pawlak, C. (2002). Correlates of Internet Use and Addiction in Adolescents. Dissertation Abstracts International Section A: Humanities \& Social Sciences, 63(5A), 1727.

Prensky, M. (2001) Digital Natives, Digital Immigrants. On the Horizon MCB University Press, Vol. 9 No.5.

https://www.marcprensky.com/writing/Prensky\%20-\%20Digital\%20Natives, \%20Digital\%20lmmigrants\%20-\%20Part1.pdf Accessed: 16/01/2015

Prensky, Marc (2009) "H. Sapiens Digital: From Digital Immigrants and Digital Natives to Digital Wisdom," Innovate: Journal of Online Education, Vol. 5: Iss. 3, Article 1. Available at: http://nsuworks.nova.edu/innovate/vol5/iss3/1, Accessed: 07.05. 2018.

Prensky, Marc (2012). From Digital natives to digital Wisdom. USA: Corwin A 
Sage Company.

Prensky, Marc (2016) Education to better their World, Unleashing the Power of 21st-Century Kids. NewYork: Teachers College Press.

Schiller, H (1993). Zihin Yönlendirenler, İstanbul: Pınar Yayınları.

Stark, L. and Crawford, K. (2015). The Conservatism of Emoji: Work, Affect, and Communication Social Media + Society, July-December 2015: 1-11. Sage.

Strauss, A. and Corbin, J. (1998). Basics of qualitative research: Techniques and Procedures for Developing Grounded Theory. Second edition. Thousand Oaks, Calif.: Sage.

Sugiyama, S. (2015). Kawaii Meiru and Maroyaka Neko: Mobile Emoji for Relationship Maintenance and Aesthetic Expressions Among Japanese Teens. First Monday peer-reviewed Journal on the Internet, vol. 20, no. 10. http://journals.uic. edu/ojs/index.php/fm/article/view/5826/4997A Accessed: 29.09. 2017.

Walther, J. B. and D'Addario, K. P. (2001). The Impacts of Emoticons on Message Interpretation in Computer-Mediated Communication, Social Science Computer Review. Vol. 19 Iss.3, 324-347. Available at: http://hc.rediris.es/pub/bscw.cgi/ d3323568/impactoemoticones.pdf, Accessed: 20.05.2018

Yıldııım, A. ve Şimşek, H. (2005). Sosyal Bilimlerde Nitel Araştırma Yöntemleri, Güncelleştirilmiş Geliştirilmiş 5. Baskı, Ankara: Seçkin Yayınclık. 